\title{
Divine Insights, Cosmic Harmony
}

All the texts examined so far are in some way concerned with trajectories of initiation. Since kingship and administration are related to celestial forces, truths accumulated in the tradition, and insight into fundamental principles, it is inevitable that the prince is not only generally educated, but more specifically initiated into the secrets of his status, to prepare him for his future task. But not only princes should be alerted to their place within the configuration of the world and the cosmos, kings, too, should be reminded of their responsibility, and viziers and ministers can function satisfactorily only when they are endowed with supreme insight and intuition. Even if the basis of correct rule is rationality and justice, this rationality is not just invented in the human mind; it is a constitutive principle of Creation and derived from the fundamental framework of religion. Insight is thus often related to revelatory experiences, epiphanies, and the exploration of secret realms. As the examples in the previous chapters show, there is no knowledge without insight, no ability without recourse to a supernatural order.

As we have seen in the different kinds of texts discussed above, this initiation is not an isolated phase in which the prince or the vizier is instructed, and in which some form of 'secret' knowledge is instilled in the prince; it is simultaneously a phase in which the prince is confronted with the occurrence of evil, supernatural forces, which threaten the harmony of human life on earth and aim to counter God's intentions. Besides representing the divine scheme, the king has to subdue the forces undermining it in the form of spells, magical interventions, and, more generally, the whims of supernatural creatures. To establish order the prince has to conjure and control the forces conspiring to subvert it. The ability to do this and the susceptibility to receive the required initiation are, of course, not given to just anyone, but are strictly reserved for a chosen few. They belong to the prerogatives and tasks of the 'true', authentic king, chosen by God to represent him on earth.

In this chapter we will analyse three texts that illustrate the relationship between rulership, both of the king and his minister, and divinely inspired insight and esoteric knowledge, and the ways in which these are embedded in concepts of social and cosmic harmony. The narratives show procedures of initiation, the conjuring of evil forces, and the idea of chosenness in various forms, referring to different conceptualizations of the universe and its relationship to the human realm. To a certain extent, the theme of this chapter is a continua- 
tion of the main themes of the two previous chapters, in the sense that it will show other facets of the relationship between kingship and the Divine, while it elaborates on the notion of initiation, which was already discussed with regard to the Seven viziers. The combination of the revelatory aspects of the Divine with the process of initiation emphasizes the ritual aspect of the ascent to kingship, as it is shaped in the narrative components of the discourse of authority.

\section{The Cycle of the 'Queen of the Serpents'}

Although the Thousand and one nights contains many stories that revolve around magic, jinns, and supernatural phenomena, it does not include many stories that deal more specifically with forms of esoteric knowledge. A narrative that stands out in this respect is the cycle of the 'Queen of the serpents', which even for Thousand and one nights standards is rather eccentric and complex. ${ }^{1}$ The cycle was probably never part of an 'original' version of the Nights, if it ever existed, but was presumably added in the eighteenth-century versions. The cycle is complex first of all because it consists of three rather diverse components: a framing story that relates the adventures of Hasib Karim al-Din, his initiation into esoteric knowledge and his becoming a vizier; an embedded story that presents the misadventures of Buluqiya, who, as a king, goes in search of divine/prophetic inspiration; and, contained in 'Buluqiya', the story of 'Janshah', his love for Shamsa, and his journey through the realm of Sulayman. These three stories are joined in several versions of the cycle, which indicates that they were somehow considered to be related in a generic or thematic sense. The story of Buluqiya can also be found separately in various collections of the 'stories of the prophets' (qisas al-anbiya), in which eschatological stories and prophets' lives are transmitted.

The stories are complex, too, as we shall see, because they contain motifs and material that are deeply rooted in the Middle Eastern/Asian narrative tradition and that show intriguing patterns of transmission. Some of the motifs, and perhaps whole parts of the stories, may go back to ancient times-Mesopotamia, Greece-but surviving manuscripts show that they were certainly current in the fifteenth to eighteenth centuries in the Ottoman Empire, either as a cycle or as separate tales. The story of 'Buluqiya', for instance, is included in alTha'alabi's collection of prophets' stories (eleventh century C.E.), where it is

1 For a summary of the story and references, see: Marzolph and Van Leeuwen, The Arabian Nights Encyclopedia. 
classified as part of the material from Jewish sources, the 'Isra'iliyyat'; there also exists a Spanish version, and in Turkish it is found in various versions from the fifteenth century, and it is preserved in an African version as well; it is mentioned as a commonly known tale in an Ottoman travel account of the fifteenth century; and it is found in the story collections by the French 'jeunes de langues', who studied Oriental languages in Istanbul in the seventeenth/eighteenth centuries. It is also incorporated in Dom Chavis's compilation of the Thousand and one nights, translated by Cazotte. Another Arabic version is incorporated in a manuscript from the sixteenth century. ${ }^{2}$

It is convenient to begin our discussion with the story of 'Buluqiya' and then examine its thematic links to the framing tale of the 'Queen of the serpents'. The contents of the story are briefly as follows: Buluqiya, the son of a Jewish sage and king of Egypt, ascends the throne after his father's death. In the treasury he finds an ebony chest containing a document that relates the life of the Prophet Muhammad. Elated, Buluqiya decides to set out on a journey in search of Muhammad. In Jerusalem he meets the sage Affan, who tells him that they should travel to the tomb of Sulayman (Solomon) to obtain his ring, which will give the owner not only the authority over all living creatures, but also allow him to go to the Fountain of Life. There Buluqiya will acquire enough lifespan to encounter the Prophet in the distant future. In order to be able to reach Sulayman's grave, however, they have to find the Queen of the serpentsmistress of the snakes of hell-who can give them a magical herb enabling them to cross the seven seas. When they finally reach the tomb of Sulayman and try to steal the ring, Affan is killed by the serpent guarding he tomb. Buluqiya is miraculously saved by the archangel Jibril (Gabriel).

In the second part of the story, Buluqiya roams seas and islands where he witnesses the wonders of the world. He visits warring jinn tribes and their kings and is shown the mechanisms of the cosmos by the angels responsible for the alternation of night and day, earthquakes, war, and prosperity. The angels on Mount Qaf, the mountains surrounding the inhabited world, explain to him the regions of the cosmos and the enormous cosmic beast carrying it. Continuing his journey, he meets a young man weeping beside a grave. It is Janshah, who

2 Jorge Pascual Asensi, “Tras los "signos de la profecía": a propósito de las fuentes ideológicas y literarias del Fecho de Buluqiya y su pervivencia en la literatura piadosa de los moriscos', Sharq al-Andalus 18 (2003-2007) 173-201; Victor Chauvin, Bibliographie des ouvrages arabes ou relatifs aux arabes (Liège and Leipzig, 1903) vol. 7; Comte de Caylus, Contes, Julie Bloch, ed. (Paris, 2005); Jacques Cazotte, La Suite des Mille et une Nuits, Raymonde Robert, ed. (Paris, 2012); La docte Sympathie: Tawaddud al-Jâriya. Conte des 1001 Nuits-version de Tombouctou (Paris, 2015). 
tells him the story of his misfortune. ${ }^{3}$ Finally, Buluqiya arrives at a paradisiacal island where he is picked up by the saint al-Khadir (al-Khidr), who takes him home, where he resumes his kingship.

The story of Buluqiya belongs to the genre of the 'stories of the prophets', which assembles not only the life stories of the Muslim prophets, but also, usually, accounts of an eschatological nature, visions of heaven and hell, and the adventures of the jinn. It is not part of the revelation, but it provides the narrative material surrounding figures and events referred to in the Qur'an, as a kind of supplementary mythology. The provenance of the stories is usually biblical stories, Jewish traditions, and Arabic lore. The material was gathered in the centuries after Muhammad and recorded in written collections, within works of Qur'anic exegesis, and oral circuits. It subsequently found its way into folklore and fictional literature of various kinds, especially tales of magic and jinns, which are often, partly, situated in a realm outside, but penetrating, the common human world. These tales are usually not perceived as 'high-brow' literature, but rather as fanciful trivialities meant to entertain the audience. 'Buluqiya' is different, however, because it has preserved its association with the 'stories of the prophets' genre in spite of its incorporation into the more frivolous corpus of the Thousand and one nights.

Most scholars place the story of Buluqiya among the eschatological narratives transmitted within the Jewish tradition but ultimately going back to motifs from the Mesopotamian tradition, such as the Epic of Gilgamesh. An element that indicates Mesopotamian origin is the document found hidden in a casket that contains some secret wisdom. Moreover, from ancient times the Israelites are portrayed as the guardians and transmitters of the esoteric and magical sciences. In the case of 'Buluqiya', this ancient material was adapted to suit the Islamic environment, by introducing the Prophet Muhammad and accommodating the supernatural phenomena to the Quranic vision of the universe. In this sense, it resembles the story of Tamim al-Dari, another Arabic anti-hero, who leaves his home to visit the wondrous realms of creation only to return after many years have passed. That these stories were current among the Ottoman elite in the sixteenth century is attested to by the travel account of Piri Reis, who, after being shipwrecked on the Indian coast, undertook a hazardous journey to return home. When the famous sea captain relates the events of his adventurous journey to the governor of Amid, in Anatolia, the latter remarks: 'It is like the stories of Temim Addari, Belkiyya and Janshah!"4

3 The story of 'Janshah' will be discussed in Chapter Five.

4 Seyyidî Alî Re'îs, Le Miroir des pays. Una anabase ottomane à travers l'Inde et l'Asie cen- 
The basic form of the story of 'Buluqiya', stripped of its contexts of cultural roots and framework, is a journey of initiation, with its narrative devices, such as a succession to the throne, the prince's departure from home, his crossing several metaphorical/geographical boundaries, and the conveying of new, instructive, knowledge. Helped by a sage, and later by angels, Buluqiya is gradually introduced to a segment of the universe normally outside human perception in which the natural forces are structured and regulated. Buluqiya's education comes not only from his visits to exotic, mysterious realms, such as the many marvellous islands, Mount Qaf, and the world of the jinns; his instruction includes the forces of nature and the cosmic setup. All these elements belong to the realm governed by Sulayman, who is the king of the (super)natural world and the key figure of the story, giving access to the treasury of secret knowledge. It is, in the end, a world of wisdom and knowledge, which Buluqiya acquires through both visual observation and descriptive accounts and which gives him insight superior to that of other men.

The perspective of the story is completely changed by the incorporation of Muhammad. Whereas the central figure in the story is Sulayman, who is, however, deceased and therefore relegated to the past, although his powers remain in full force, the dominating figure of the future is Muhammad, who is retroactively projected into the past. As we will see below, conversion to Islam before the advent of Muhammad, and thus before the actual revelation of the Qur'an, is a topos recurring in Arabic romances of chivalry. The hero catches a glimpse of God's truth and begins to act according to His will, even before it is disclosed to man. This shows that even before Muhammad's birth, the world was designed and ordered according to God's plan, centred around the many successive prophetic figures, such as Ibrahim, Musa, Sulayman, and Jesus. The pre-revelation heroes of the stories all strive fervently to refurbish the world to prepare the way for the prophet. Buluqiya's awareness of Muhammed reveals the prophet as an instrument of God to finalize the creation of the world and mobilize the forces of good in order to fulfil God's scheme. At some level, past, present, and future interact outside the reach of man, who is imprisoned in his lifetime but can achieve a deeper knowledge of reality.

The incorporation of Muhammad into the story is, of course, intended as a means to link the message of Islam to the ancient cosmological traditions and to situate the prophet in a single, continuous tradition of wisdom and revelation. Buluqiya conquers a specific place in this tradition, but his abilities

trale, trans. Jean-Louis Bacqué-Grammont (Arles, 1999) 130 (my translation from the French translation). 
are limited. His ambitions come close to hubris, as is shown by the figure of Affan, who is a sage seeking power over the natural forces by appropriating Sulayman's ring. He is killed for his audacity, but Buluqiya is saved because his intentions are impeccable, and he is allowed to acquire a share of secret knowledge. However, he ultimately fails to realize his aim, that is, meeting Muhammad, because he is bound to his time and has not been chosen to become a prophet himself. His role is to use his superior knowledge in the exercise of his royal authority and to thereby foster the effectuation of God's grand design. Although at some level this design is already realized, where time forms a unity and past and future converge, on the human level it is constructed step by step, confined by the limitations of time and place, and embodied by the personal role of each individual actor.

The esoteric purport of the story of Buluqiya is reinforced by its connection with the two other stories with which it forms a separate cycle. Although the confluence of these stories, at least in some versions, strengthens its message, it probably also marks the transition of the narrative material from a prophetic tale into a fictional frame, thereby changing not only its narrative form, its generic framework, and its interpretative perspective, but also its audience and the media by which it was conveyed; in short, it facilitated the transference of the narrative from the 'stories of the prophets' to the Thousand and one nights and Ottoman story collections, and perhaps circuits of oral storytelling as well. The story not only becomes part of the religious mythology supplementing the Qur'an, but also of the collective, even popular, imagination, amalgamating religious with popular lore. This combination is notably represented by the story of 'Janshah', which contains long episodes set in Solomonic realms, but which ultimately turns out to be a love romance, albeit between a man and a jinniyya. We will discuss this story more elaborately below, in our chapter on kingship and love (Chapter Five).

The narrative element that complements and amplifies the significance of the story of 'Buluqiya' most adequately, within the cycle of the 'Queen of the serpents' is the story of 'Hasib Karim al-Din'. This story not only serves as a frame for 'Buluqiya', it also adds to its esoteric nature and its interpretative potential. The story of 'Hasib Karim al-Din' is roughly as follows: A Greek sage named Danyal loses all his work in a shipwreck, except for five pages stored in a box. After his death, his wife gives birth to their son, Hasib Karim al-Din, who grows up as a lazy good-for-nothing, unable and unwilling to learn anything. To provide some income, he joins a group of woodcutters. One day, in the forest, the group seeks shelter in a cave, and Hasib falls into a subterranean crypt filled with honey. His comrades collect the honey, which he hands over to them, and subsequently abandon him, imprisoned, in the crypt. Hasib succeeds in finding 
an exit at the other end of the crypt, where he arrives at a large lake surrounded by a golden throne and 12,00o silver chairs. He falls asleep and is awakened by the hissing of a large number of snakes approaching him. A great snake carries a plate with a small snake with the face of a woman: Yamlikha, the Queen of the serpents. The Queen tells Hasib the story of Buluqiya and also about her meeting with him and the story he told her about Janshah.

During the account of the Serpent Queen, Hasib repeatedly asks her to release him and let him return to the human world. In the end the Serpent Queen agrees to do so, but only after Hasib has promised never to enter a bathhouse in the future, since this will cause her death. After the Serpent Queen has finished her story, she finally lets Hasib return to the surface of the world through a deserted well. Sometime later, Hasib is seduced by his friends to go to a bathhouse, in spite of his promise. There he is suddenly arrested by slave-soldiers, who see that his body is covered with black spots. They take him to the palace of the king, who is gravely ill and who has heard that the Serpent Queen will provide him with medicine and that Hasib can bring her to him. With some reluctance, Hasib leads the wicked vizier of the king to the well and the Serpent Queen appears. She instructs Hasib in secret to cut her body into three pieces, boil one part of the meat and pour the broth into two phials. The vizier will ask him to drink from the first phial, but he should drink only from the second phial and offer the first one to the vizier. After this has been done, the vizier drinks from the first phial, swells up and dies; Hasib, who drinks from the second phial as instructed is suddenly struck by a strange perspicacity: $\mathrm{He}$ has insight into all sciences, mineralogy, medicine, chemistry, the art of making gold and silver, astrology, alchemy, natural magic, the Cabbala, and Spiritism. The king is cured by the medicine and appoints Hasib as his new vizier. Hasib now reads the five pages left to him by his father.

It is clear that the story of Hasib Karim al-Din and the Queen of the Serpents - curious even by Thousand and one nights standards - is rich in references to ancient narrative material. Here, again, we meet the ancient Mesopotamian motif of the lost wisdom, part of which is saved and kept in a box by a Greek/Jewish guardian/sage. The motifs of the snake and the cave connected with trees also reflect Mesopotamian stories. As we have argued elsewhere, ${ }^{5}$ the story also seems to be part of the Neoplatonist tradition that was transmitted to Arabic and Persian philosophy through the cults of Harran, the translation of works by Porphyry, Pythagoras, and Iamblichus, and the philosophies of al-Razi $\left(865^{-925)}\right.$ and al-Suhrawardi (1154-1191). This connection is sustained mainly

5 Van Leeuwen, The Thousand and One Nights. 
by the complex motif of the cave, the honey, and the lake as a transitory space from the human realm to a subterranean, supernatural realm. This motif can also be found in Homer's Odyssey, as the cave of the Naiads, and it is discussed by Porphyry (c. 234-305 C.E.) in his treatise On the cave of the nymphs. This hypothesis of a connection between these texts is strengthened by the fact that the Serpent Queen's name is Yamlikha, which is the Arabic form of Iamblichus, the Neoplatonist philosopher (c. 250-330 C.E.). Intriguingly, the motif of a cave with a double exit haunted by bees and snakes can also be found in the novel 'A Babylonian story', written by a writer who is also named Iamblichus, who lived in the second century CE.

Apart from the name Iamblichus, a Neoplatonist interpretation of the story is supported by the context. A Neoplatonist element, for instance, may be the taboo on bathhouses, which can be found within Pythagorean esotericism as well. But more convincingly, the story echoes the debate between Porphyry and Iamblichus about the theurgical potential of ritual. In his treatise on the cave of the Naiads, Porphyry discusses the cave as an esoteric metaphor for the transition from the human to the divine world, the cave being the locus where secret knowledge is stored and where earthly, material possessions are given up and exchanged against divine insight. In another treatise, Porphyry discussed the possibility of eating animal flesh as part of esoteric ritual. The treatise was directed against Iamblichus, who held that it was possible for humans to influence the spiritual realm by rituals, and even to reach a state of illumination, of half-divinity. In contrast to Porphyry, Iamblichus did not exclude the sacrificing and consumption of animal flesh as part of these rituals. It was especially these theurgical theories of Iamblichus that were popular in Harran in Islamic times. It seems that Iamblichus and Porphyry are the key figures of this line of interpretation, as evidenced by several motifs: the motif of the cave as a boundary between two realms; the ritual sacrificing of the flesh of the Serpent Queen; the renouncing of material possessions (honey); the figure of Hasib Karim al-Din as chosen by destiny; and the final state of insight and illumination. All these motifs neatly conform to the Neoplatonist views of life, the world, and the universe. ${ }^{6}$

But this is not all that can be said about the potential sources of the story. There seems to be a Persian trajectory as well, as is indicated first of all by

6 See about Iamblichus, Porphyry and Neoplatonism: Gregory Shaw, Theurgy and the Soul: The Neoplatonism of Iamblichus (University Park, PA, 1995); Michel Tardieu, 'Sabiens coraniques et "Sabiens" de Harran', Journal Asiatique 274 (1986) 1-44; Porphyry, Select Works of Porphyry, Thomas Taylor, ed. (London, 1823); Iamblichus' novel in: B.P. Reardon, ed., Collected Ancient Greek Novels (Berkeley, 1989). 
the fact that in several versions of the 'Queen of the Serpents', the hero is not called Hasib Karim al-Din, but Jamasp. The name Hasib may even be a corruption of Jamasp, as both names have virtually the same consonants in nonvocalized and undifferentiated Arabic script. Jamasp was a legendary Persian sage, the main prophet/philosopher after Zoroaster, who was famous for his knowledge of the secret sciences such as astrology, alchemy, and geomancy. He is associated with the apocalyptic work 'Jamaspnama', which recurs in the literary tradition as a compendium of religious and esoteric knowledge. Fleischer describes a manuscript titled 'Jamaspnama' that contains an Ottoman-Turkish version of the cycle of the 'Queen of the Serpents', including the stories of Hasib Karim al-Din/Jamasp, Buluqiya and Janshah. According to Fleischer, this text, which roughly follows the Thousand and one nights version, is a translation of a Persian version, made in 1429-1430. ${ }^{7}$ Several Turkish versions of this text from the subsequent centuries have been preserved. Another Turkish text containing the motif of Yamlikha as King/Queen of the serpents is the epic romance of Sayyid Battal, which could be as old as the eleventh to thirteenth centuries, but which seems to be more convincingly a romance describing the Ottoman struggle against the Byzantines in the fifteenth century (see Chapter Four).

This evidence may perhaps point not to a Persian origin of the story, but certainly to an eastern 'branch' of it. An Arabic version dating from the sixteenth century also has Jamasp as its hero. This manuscript is part of a collection titled Makhtuta Taymuriyya, which may reflect an Oriental origin of the material, perhaps even its provenance from the Timurid lore on its westward journey. Jean-Claude Garcin, mentioned above, has surmised a connection between narrative material in Arabic, and more specifically in the later versions of the Thousand and one nights, and the return of Arabic literati from the Timurid court at the beginning of the fifteenth century. Another remarkable element is the reference to a pavilion with two exits in the Hindi romance Madhumalati (sixteenth century; see Chapter Five). Here some young maidens playing in a garden are attacked by bees and flee into a pavilion that contains marvellous images of the world. They leave the pavilion at the other side, 're-born' in another state of mind. Could it be that the whole motif-complex of the cave, the honey, and the serpent—or parts of it—is derived from Indian examples? ${ }^{8}$

7 H.L. Fleischer, Kleinere Schriften. Gesammelt, durchgesehen und vermehrt (Osnabrück, 1968) vol. 3, Xva; Xvb; XvI, 226-26o.

8 Heinz Grotzfeld and Sophia Grotzfeld, Die Erzählungen aus 'Tausendundeiner Nacht' (Darmstadt, 1984); Garcin, Pour une lecture historique; Manjhan, Madhumalati: An Indian Sufi Romance, trans. Aditya Behl and Simon Weightman (Oxford, 20oo). 
And how would it relate to a Neoplatonic interpretation? We will have to wait for new evidence to answer these intriguing questions.

The speculations above about the origin and trajectory of the story of the 'Queen of the Serpents' do not result in a clear pattern of transmission. They do show, however, how persistent literary motifs can be within trajectories of transmission over long stretches of time and space. These trajectories were certainly influenced by the political frameworks in which they evolved, but they also possessed their own dynamics and force, enabling them to become incorporated into new narrative embeddings and be endowed with new, added meanings. It is not without significance that these 'memes' survived from ancient times until the eighteenth century, when they were incorporated into the Thousand and one nights and became part of its 'modern' tradition, being translated into a European language for the first time in the eighteenth and nineteenth centuries. The cycle reveals the complex background of the Ottoman literary/cultural imagination, its function as a repository of various cultural influences and literary material, and its role as a bridge between Asia and Europe.

But what do these stories tell us about visions of kingship? First of all, we find the familiar basic elements of narration and dialogism: instruction and initiation take place through narration, through the conveying of knowledge to a 'prince', making use of a combination of texts of different generic types; second, the dramatization takes off from a potential break, the loss of knowledge and the perdition of the kingdom, which is associated with the motif of silence; third, the prince is chosen by destiny to perform his role; he is driven towards his itinerary, he is surrounded by taboos and evil forces, but he is in the end the one who assimilates insights that have been pre-ordained for him from the beginning; fourth, the initiation can be compared to a revelation, an awareness of a divine nature is granted to the prince that gives him insight into the secrets of the universe; fifth, the initiation of the prince is quite elaborately linked to the tradition of wisdom and knowledge, reaching back to ancient times, but it is also related to a new, religious, phase in history, heralded by the advent of Muhammad. The roles of the prince and his knowledge are ultimately part of God's scheme to transform the world according to His plan, using the characters in the story as actors to foster this process and, at the same time, as media spreading knowledge and insights about His universe. Finally, kings are far from common people; they are selected to perform their predestined roles and they are endowed with a superior form of insight and communication with a higher spiritual/religious realm. This insight implies a breach with the past, but also a new beginning, or at least a vision of the future. We will see this historical transition more prominently in our discussion of chivalric romances. 
To conclude, it should be noted here that in the 'Queen of the serpents' the chosen initiate is not the king but his vizier, who, starting as a useless brat, turns out to enjoy the privilege of esoteric insight. This trope of the prodigiously insightful vizier is also found in the figure of Shimas and his son, and in the genie/vizier of Vikramaditya, in the Twenty-five tales of the genie, and, of course, in the figure of Jiang Ziya, in Creation of the gods. This does not mean that the vizier is superior to the king, but rather that he has a different role, and that his contribution is an essential component of kingship as a divinely given institution.

\section{King and Cosmos: The Sorcerer's Revolt}

The cycle of the 'Queen of the Serpents' shows a literary representation of the links between kingship and rule and the cosmic forces determining human destinies. A similar pattern can be seen in a remarkable Chinese novel from the seventeenth century. This novel was compiled by the well-known author Feng Menglong (1574-1645), who probably made use of material from longstanding oral tradition. The book can be classified as a novel, but it contains a rich substratum of episodes depicting life and beliefs in Ming China adding plotlines to the already complex narrative. Unlike the story of the 'Queen of the Serpents', it is not an esoteric story; it rather displays the permanent interaction between the cosmic realm, esoteric knowledge and abilities, and common human life. As in the novel Creation of the gods, discussed above, whatever happens in the novel is related to some cosmic event, or vice versa, and esoteric knowledge, derived from Buddhist and Taoist teachings, serves as a medium to regulate (or deregulate) the interaction between the realms. But while it uninhibitedly indulges in celestial imaginings, the novel also portrays common society and common man.

The story begins by relating how Xuan Nyu, also called Mystery Girl, Dowager Queen of the Ninth Heaven and Teacher of the Realm in the martial arts, encounters Yuan Gong, a white ape versed in the teachings and lifestyle of Taoism, and how she takes him to the Yellow Emperor in the Ninth Heaven as her servant. The ape-god is assigned to guard the Mysterious and Marvellous Secret Books, containing knowledge that never reached human ears or eyes. Although the ape is not allowed to peek into the books without the permission of the Ministry of Cultural Affairs, one day, during the birthday celebrations of the upright Golden Mother of Western Heaven, Yuan Gong is left behind and, bored, starts to browse through the secret books. He finds a small, closed box, which he opens by invoking the help of Mystery Girl, while promising that he 
will not use sorcery for evil purposes. In the box he finds the One Hundred and Eight Charms for the Transformation of Forms, the Thirty-Six Greater Transformations listed in accordance with the principles of divination by hot, dry winds of highest heavens, and the Seventy-Two Lesser Transformations, listed in accordance with divination by the cold, damp spirits of deepest Earth. And there is a marvellous formula for altering the course of the heavens and moving the Pole Star, miraculously useful in battering against ghosts and in harnessing spirits.

Pleased, Yuan Gong returns to White Cloud Cave on Mount Dream-of-the Clouds, his earthly abode, with this Concordance of the Will of Heaven, and carves the formulas on its walls. This is evidently a gross violation of Heaven's regulations, transferring secret knowledge to the earthly realm without permission of the Jade Emperor, while the hearts of men and women are not sufficiently righteous. ${ }^{9}$ Yuan Gong is brought before a Heavenly tribunal of the Royal Attendant of the Cultural Affairs Bureau and the Star Lords. He is accused of breaking the heavenly seals without authorization and stealing Heaven's secret Teachings. Yuan Gong defends himself: 'It is often said that the Emperor of Heaven is not selfish, so I didn't believe that he could have any secrets. If he did have secrets, they shouldn't have been written down. But as they are indeed written down, they should be transmitted throughout the ages. The Jade Emperor's storing them in a box and my carving them on the walls are one and the same thing.' ${ }^{10}$ Furthermore, he claims to have obtained the permission of the Mystery Girl, because he succeeded in opening the box only after invoking her help. After writing his penitence and promising to make amends, Yuan Gong is allowed to leave and reform himself. The Emperor rescinds the death sentence but orders him to guard the White Cloud Cave solitarily; the title Lord of the White Cloud Cave is changed into White Ape God. A Magic Lamp of Wishes will indicate Yuan Gong's adherence to his vow, and the Cave will be protected by a curtain of fog.

From here, the story continues on earth and gradually zooms in on an old vixen, a celestial fox endowed with magic powers, called Holy Auntie, and her daughter Hu Mei and son Hu Chu, or Quezi. Holy Auntie's skills in sorcery are limited, since she does not possess real Taoist craft, and, following an old adage, she decides to set out with her children to Dream-of-the-Clouds and the White Cloud Cave to learn Taoist magic. On the way she leaves her son behind in a Taoist temple to be taught Tao. At one point during her journey,

9 Feng Menglong, The Sorcerer's Revolt, trans. Nathan Sturman (s.l., 2008) 21.

10 Ibid., 24. 
Auntie herself is suddenly taken to heaven for a meeting with Empress Wu Zetian, formerly of the Tang dynasty, because the fates of the two women were linked. The empress, who is now a fox-spirit, tells Holy Auntie about her downfall during her life on earth and her resentment of the rebellion against the Tang emperor. After her 'worldly fate', Heaven sent her back to rule, but she could not prevent Huang Chao, the leader of the rebellion, from usurping the throne, since 'mortal men and women are different according to their times, but we spirits are the same throughout the ages. When I was Empress $\mathrm{Wu}$ on earth, the time when anyone could take the throne had come.'11 She proceeds by recounting how, in a previous life, Holy Auntie's daughter was a man, who was her-the empress's - lover. It is predicted that she will become an imperial concubine, but will ultimately be transformed into a queen who, after the empress is turned into a man, will be her/his wife. Thus, a secret bond is established between the two women, who will meet again in twenty-eight years. Holy Auntie promises to improve her magic skills to help bring about this exalted outcome. When Holy Auntie regains consciousness, she notices that her daughter has disappeared. ${ }^{2}$

After this peculiar intermezzo, Holy Auntie continues her journey and establishes herself as a Taoist nun who has received the Sixteen Scriptures from the Puxian Bodhisattva and who is able to read the most cryptic sutras. But although she is proclaimed a bodhisattva, she is still incapable of real sorcery and true spiritual greatness. In the meantime, an old Bonze finds a mysterious egg in the temple garden. He lets the egg be hatched by a goose, but remarkably a tiny infant comes out of it. Appalled, he tries to bury the child, but it keeps finding its way to the surface and grows at amazing speed. Finally, he accepts the child and names it Bonze Dan, meaning Bonze Egg. The boy turns out to be a brilliant pupil devouring the classics and soon embarks upon a life as a wandering monk. One day he hears about the secret charms in the White Cloud Cave and decides to steal them. After two futile efforts, he finally succeeds in copying half of them, after promising, with all his heart, to assist Heaven and follow Tao, and never to use them for evil purposes. However, he is unable to read the formulas.

In the meantime, Holy Auntie has become a venerated saint, due to the protection of Deputy Yang, who is a religious fanatic. Inevitably, she will be united with Bonze Dan, who, after his wanderings, is led towards her. When they meet, they immediately recognize each other as 'brother' and 'sister':

\footnotetext{
11 Ibid., 75.

12 Ibid., 75, 78.
} 
And for a couple of moments there was only silence between them, until the two inevitably began bantering in ghost talk. And this meeting in large part tells us that a monk who has stolen Heaven's secrets will soon become conversant in their tadpole-like script, while an old hag of a sorceress will suddenly change from a cloistered reader of the sutras into a fearsome goddess of evil..$^{3}$

And the cost of the meeting will be high. At once both Bonze Dan and Holy Auntie understand the prognostic dreams and formulas they have received and together they decide to set up a temple to practise the secret charms stolen by Bonze Dan, to produce gold through alchemic experiments and to summon the spirits obeying their commands. Holy Auntie also recovers her son Quezi, who is now versed in Taoist magic.

The story now turns away from Holy Auntie and Bonze Dan to focus on Emperor Zhenzong, who is in a bind because of the threat of the barbarians on the north-eastern frontier. A 'smooth talking' official advises him to arrange for a ceremonial investiture at Mount Taishan to receive Heaven's blessings and to have the dynasty properly consecrated. He asks the help of a Taoist monk, who applies charms that make the emperor dream that secret writings will be sent down from Heaven for his 'pious and devout' use. The emperor issues a decree that everyone who has received a book with Heaven's writings should present himself at the imperial court: 'And if such a person should already be an official of mine, his salary and benefits will be enhanced greatly. ${ }^{\prime 14}$ As may be expected, the prime minister succeeds in tracing a Taoist book tied at an ornamental owl's tail. Soon reports of other findings of secret books flood in.

Since Zhenzong has no successor to the throne, he sends a proclamation to the monasteries to pray and sacrifice to the Jade Emperor to give him a son. Thereupon the Jade Emperor sends a fairy to earth to become the child of the imperial concubine and later become Emperor Renzong. In the meantime, $\mathrm{Hu}$ Meir, Holy Auntie's daughter, succeeds in penetrating court circles and transfigures into the daughter of a prominent squire. Eventually, Holy Auntie gives her a book of magic, which helps her to advance. She marries the vicious Squire Wang, who, it turns out, is a male reincarnation of the aforementioned Queen Wu Zetian, who had been her lover four hundred years ago, in a previous life. In the meantime, Holy Auntie and Bonze Dan have gathered a band of sorcerers who pester and deceive the people. The news about their vicious

\footnotetext{
13 Ibid., 155 .

14 Ibid., 195.
} 


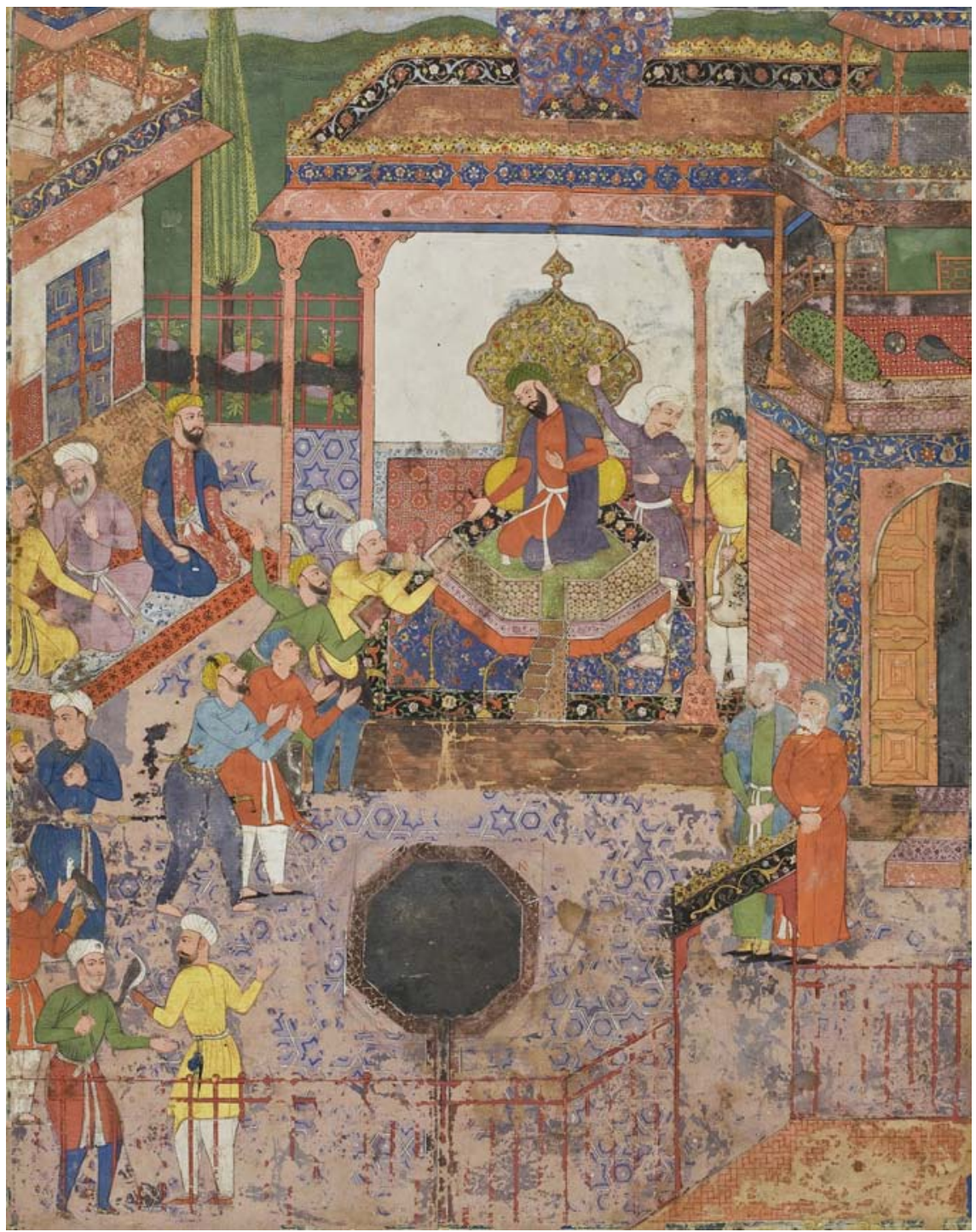

FIGURE 4 Emissaries bring news from the provinces of Khaybar and Chin to Anusherwan, from the Hamzanama, 16th century.

activities reaches Emperor Renzong, who orders a campaign to eliminate them, but he is surrounded by unworthy, evil, officials, and everywhere the conditions deteriorate and revolts break out. Holy Auntie's band of sorcerers conspires with Squire Wang, who starts a revolt and, with the help of the sorcerers, seizes the throne of the Eastern Peace County. Hu Meir now becomes queen, Holy Auntie becomes Queen Mother, and they all indulge in a life of decadence 
and abuse. Only Bonze Dan has left the group and has retired to the Spring of Sweetness Temple, because he realizes that the new government is not in accordance with the rules of Heaven and that the people are suffering.

The news of the disruptive activities of the sorcerers, the spread of corruption, and the revolt finally reaches the Palace of Heaven and the Lord of the universe, the Jade Emperor. An investigation reveals that 'the theft of the codes by some mortal has resulted in an incident that has harmed the people, and so collective punishment of all involved is proper and fitting. ${ }^{15}$ However, some culprits were only deceived by others and are therefore less culpable, and even the Heavenly institutions are not without blame:

Our Board of Astronomy failed to predict that the heavenly writings of White Cloud Cave would come to light and that the resulting sorcery would spread down the present day, emboldening that fox's party to bring about this catastrophe. It was all enumerable by Fate and none of the fault lies with the White Ape God. The writings of Heaven were actually stolen by Bonze Dan. ${ }^{16}$

Further investigations bring to light that the rebellious Squire Wang Ze is actually destined for rebirth in China every five hundred years as a devil king, 'with an appetite for lewdness, killing and revolt, disturbing the balance of the cosmos. Such a devil can only be restrained by a truly enlightened leader. Those forged books of Emperor Zhenzong's time had mocked Heaven with ghost tales and fermented all sorts of disorders, planting the roots of sorcery.' ${ }^{17}$ These mishaps in the end resulted in the birth of Wang Ze, who was destined to rule for thirteen years.

While these procedures are going on, the struggle on earth continues. Mystery Girl, the martial goddess, is sent to exterminate the forces of evil, with the help of a holy monk, who turns out to be Bonze Dan, now the adversary of Holy Auntie. Mystery Girl discovers that the orthodox laws had been written on the right-hand wall of the White Cloud Cave and the malignant charms on the left-hand wall. It was the latter that were used by the malevolent sorcerers. Now the 'genuine truth' will be mobilized against these harmful charms and 'heterodox evil will be rectified by religious truth'. ${ }^{18}$ Needless to say, Mystery Girl succeeds in subduing the revolt and capturing Holy Auntie, whom she

\begin{tabular}{ll}
\hline 15 & Ibid., 438. \\
16 & Ibid. \\
17 & Ibid., 439. \\
18 & Ibid., 455.
\end{tabular}


unmasks before the Palace of Heaven's Bright Treasure Mirror of Sorcery. Holy Auntie is led before the Jade Emperor and imprisoned. Bonze Dan, who helped Mystery Girl to gain the upper hand, is still venerated, and the White Ape God is restored to his former position of Lord of White Cloud Cave and guardian of the secret writings in the Cultural Affairs Ministry in Heaven.

This summary of The sorcerer's revolt does only limited justice to the complexity of the novel. At several points the story branches out to include subplots or to describe the backgrounds of characters or to display the workings of magic. Colourful scenes present glimpses of common life and not only weave in the personal vicissitudes of a large number of characters, but also highlight and criticize instances of corruption, oppression, greed, and fraud. All kinds of tricksters pass by to strip the people of their money or to gain prestige and status, often by magic, pretended magic, or outright deceit. Feng Menglong's social interest and the way he expresses it are not only evidence of his proficiency as a writer, but also reflect the concerns of his time. The late Ming dynasty is usually considered as a period of enlightened despotism gradually slipping into an oppressive regime, but also as a period in which arts and sciences blossomed, and literature, in particular, reached its highest peaks. Feng Menglong's novel should be ranked among such contemporary masterpieces as The dream of the red chamber and The outlaws of the marches, which also present a sublime portrait of life in imperial China.

As is often the case in Chinese literature, the main narrative is embedded in a framework of historical references. The novel opens with a mention of the Tang Emperor Xuanzong and the ministerial controversy that enabled An Lushan (713-742) to revolt against him. Subsequently, the war between the kingdoms of Wu and Yue elicits the intervention of Nyu, or Mystery Girl, and the confrontation between her and Yuan Gong. Empress Wu Zetian is also a historical figure of the early Tang dynasty, and the actual story of Holy Auntie begins in the reign of the Northern Song Emperor Zhenzong (998 C.E.). This is also the period in which the revolt takes place, under Zhenzong's son and successor Renzong. The rebel Wang and several other officials involved in the revolt or the counter-expedition are also modelled on historical persons. Finally, one of the inserted stories is the episode of the Shang Emperor Zhou, who is manipulated by his concubine Daiji, who is possessed by a fox-spirit, until King Wu founds the new Zhou dynasty. This episode provided the basic plot for the novels 'The expedition of Wu' and Creation of the gods discussed in the previous chapters. These historical narratives were probably well known among literati and perhaps even among the general—educated—audience.

The framework of historical references adds a sense of realism to the narrative, but in the worldview of the novel earthly history is a relative notion. From 
the beginning it is made clear that history as experienced by humans is only one of the components of a reality that encompasses the totality of the universe. What happens on earth is in no way separated from the celestial spheres and the Heavenly residences of the divinities and immortals. Whereas stories from the Muslim traditions show a certain interaction between the supernatural and human domains, represented by localized enchantments and marvellous journeys, in The sorcerer's revolt there is no clear separation, with the protagonists travelling to the heavens and back, even dwelling in a kind of realm of total time. This does not mean that these realms form a single amalgamated whole; the interaction is rather regulated and segmented according to individual destinies and behaviour, and ordered in a hierarchical system. The individual's place in history is determined by fate, surely, but its manifestation cannot always be predicted. Fate has to be enacted by humans and other creatures, and is often revealed only when specific events have occurred or when the course of events has taken a specific turn.

The complex interaction between the various domains of the universe takes place through magic and sorcery, but more systematically through transformations and transmigrations. People who die do not vanish, but enter a new phase in their existence, possibly in another realm. Conversely, gods, fairies, and immortals may assume human form to fulfil the next stage of their destiny. Therefore, visible forms are only a partial manifestation of a much broader reality. This constant shuttling between appearances does not mean that mere chaos or arbitrariness reigns. Within the process of permanent transformations there are some fixed elements. Whereas appearances change all the time, the true essence of individuals remains the same:

Now, the original soul of everything in the universe is fixed in the memory of the Eye Spirit, and though you transform yourself countless times, your true self never changes there. And as the Mirror of Heaven reflects back into the Eye's Sprit's two pupils, Chu Nyu learnt how the fox spirit became a celestial fox after years of cultivation and all about her getting the stolen arms. Watching the maiden look at her past as if on a tapestry from Heaven's loom, Holy Auntie feared the worst and closed her eyes, holding up her wrists for binding. ${ }^{19}$

Thus, there is a basic structure, a primordial stability within a fluid passage of time. The driving force within this system is Fate, but the effectuation of Fate

19 Ibid., 472. 
must be 'managed', which is difficult because no one has total knowledge of its secrets and it is only gradually and partially revealed.

Because of the essential unity of the universe, every event has its consequences within the various domains. An event on earth can have its cause in Heaven, and vice versa; an event in a distant past may cause a disruption in the far future. The workings of this interaction are beautifully shown in the novel when the process of revelation is disturbed by the Ape's negligence. This misadventure, which is largely left unpunished, causes a crack in the basic harmony between Heaven and earth, and in the sequence of time. This in turn creates the possibility of disharmony on earth fostering disobedience, corruption, rebellion, and war. This situation is exploited by the wicked Empress $\mathrm{Wu}$ Ze, who represents evil, but who is fated to reincarnate on earth to be reunited with her former lover, who transmigrated in the figure of $\mathrm{Hu}$ Meir. The result is a Faustian pact between the forces of evil in Heaven and on earth, between the Empress Wu Zetian and the fox-spirit Holy Auntie, to realize their respective aims. Only after the predestined reunion has taken place, is the Jade Emperor in Heaven notified of the ominous turn of events, and orders are issued to set things straight. Still, this can happen only once destiny has completed its course.

Within this interplay between earthly and celestial forces, the struggle to 'manage' the consequences of fate is also a struggle between good and evil. Disharmony results in opportunities for evil to expand at the expense of good. Corrupt ministers and administrators have the chance to carry out their destructive schemes, while morally upright officials and military men are marginalized and ignored. The empire falls prey to civil war and oppression. The restoration of harmony is accompanied by political stability, prosperity, and peace. But the balance between these forces is always determined by the complex framework of interrelations in which it is embedded. An evil deed in the past lingers as an unrequited debt on history and can at its predestined moment re-appear and disrupt the course of events. Conversely, suffering can be compensated for in a future life, or by a person's ascent within the hierarchy of Heaven. It is as if the universe contains a stable quantity of good and evil, which is constantly being redistributed over persons and gods, by perpetual transformation, and by the disequilibrium engendered by fate. At the same time, virtue, or its opposite, as a moral force, contributes to the shaping of these balances, since it enforces changes in the cosmic hierarchy.

What do all these observations tell us about concepts and perceptions of kingship? It is clear that notions and practices of kingship are incorporated in a broad vision of the structure of the universe. Like all other phenomena on earth, kingship is woven into the interplay of natural and supernatural forces 
determining the course of events, manifested in transmigrations, transformations, and the hierarchies of authority and esoteric competence. The intricacy of these forces has as a consequence that it is not always clear where agency and the responsibility for acts and occurrences lie. Of course, the whole cosmic structure is moulded into hierarchies, with at the top, on earth, the emperor, and, in the Ninth Heaven, the Jade Emperor. In theory, these emperors enjoy supreme authority and their commands should be obeyed, since they represent the stability of the cosmic order. Still, they are not all-powerful or omniscient, since they need the help of ministries, informers, assistants, specialists in several fields, etc., who all function within the system of powers and competences.

The emperors are thus not so much powerful in themselves, as pivots within the system that regulates the unfolding of fate. It is their task to harmonize human action, on all levels, with the incontestable power of fate, and thus they derive their authority only from the ability to influence the destinies of both individuals and large collectivities (China). It seems that in spite of the central position of the emperor, power is diffuse and not vested in individuals, but in history itself, all humans and divinities acting as the instruments for the implementation of fate, which are either seeking opportunities to act out their role, or trying to find out the nature of their role. The emperor, too, is one of the main instruments of fate, acting as a cornerstone supporting the cosmic system; but being a cornerstone, the emperor is not free to act as he pleases, but is steered by the all-powerful effectuation of fate. As we have seen in the case of 'The expedition of Wu' and Creation of the gods, the Jade Emperor represents supreme authority, but even his authority is derived from a more powerful system, and he, too, is caught in the tension between his personal responsibility and inclinations, and the 'neutral' forces that hold him imprisoned in his status.

The system of authority as depicted in The sorcerer's revolt operates within the rather dusky domain in which mythology, religion, magic, and supernatural powers prevail. In order to develop power within this system several forms of insight are required, which have to be linked to effective means to exert power. Holy Auntie has acquired magical abilities, allowing her to help the rebellious Wang and his troops to achieve victory, which is ultimately the event enabling Empress Wu Zetian to realize her predestined reunion with her lover. It is the leaking of secret religious knowledge that sets in motion the whole process that allows Bonze Dan to fulfil his mission as a pious monk. And it is the magical capabilities of Mystery Girl that finally enable the Jade Emperor to set things straight and to suppress the revolt, after he has been informed of fate's disruptive course. Actual power is fragmented and bound, and esoteric knowledge is essential to unravel the nature and location of responsibility, 
and, to be sure, the relation between responsibility and individual destinies. This is beautifully illustrated by the tribunal at the end, when the culprits have to be determined, which, because of the inescapability of fate, is no easy matter.

The celestial tribunals and interventions show that apart from fate the main element governing the course of history is morality, that is, the balance between good and evil forces, not only on earth, but also in heaven. Esoteric insights can be used for good or bad purposes, and are linked to manifestations of good and evil on the level of ordinary humans. It is here that Feng Menglong expresses his main message: his concern with the conditions of the population of the empire and the ways in which corruption, greed, and ambition destroy the social fabric. These destructive forces are fostered by deceitful and avaricious priests, monks, and (pseudo-)sorcerers, who use 'bad' magic to achieve their aims. They exploit the gullibility and superstitions of the people and pervert religion with their fraudulent tricks. A rational view of life and a return to true religion will protect the empire against these destructive elements. This is the way to conjure the supernatural powers evoked by villains, which haunt society and undermine the administration. They need to be exorcised before the emperor can represent the harmony needed for inculcating history with moral values and harmony. This makes Feng Menglong a true representative of what may be called an enlightened view of life.

\section{Jan Potocki's Manuscrit Trouvé à Saragosse}

The examples examined in this section so far show the importance of esoteric beliefs and knowledge in the constitution of visions of kingship, authority, and society. It is well known that in medieval times, within the different traditions and cultural realms, worldviews were steeped in what would later be called superstitions, myths, and erroneous belief in supernatural forces. It is less well known that these tendencies did not die out in the core period of the European Enlightenment, the eighteenth century, but rather blossomed as never before. As esoteric knowledge was part of science in seventeenth-century China, in Europe, too, the new inquisitiveness of the Enlightenment coincided with a new, more systematic interest in esoteric sciences, partly as a search for new scientific paradigms, and partly to compensate for the diminished authority of the religious-Roman Catholic-worldview. Where the religious representation of the universe began to show fissures, glimpses of other, hidden, worlds shined through. Where the forces of angels became less persuasive, images of devils and demons and their world of magic emerged. 
In Europe, knowledge of the esoteric and occult sciences has usually been associated with the Orient, not only because it was seen as the cradle of scientific knowledge, but also because it was imagined as the region where supernatural forces could freely unleash themselves. There, other natural laws reigned, which allowed for magic and demonic creatures to intervene unhampered in human life. This vision changed during the eighteenth century, when the idea of the universality of the laws of nature gained influence and the image of a heterogeneous world gradually disappeared. Still, in literature the association between the Orient and esoteric knowledge remained, mainly because of the influence of the French translation of the Thousand and one nights by Antoine Galland. Galland's Mille et une nuits became the source of inspiration not only for a long and structural taste for orientalism in European literature; it also more specifically became a model for ways to incorporate esoteric and supernatural visions into fictional narrative.

Since in many of the Nights' stories supernatural elements (magic, jinns) interfere freely with realist descriptions of daily life, it suggested a world in which reality was not unequivocal and in which the supernatural was immanently present at all times, hidden inside the perceived material world. This literary expression of popular esotericism was one of the main sources of what came to be known as Gothic literature in its various forms. It is exemplified by authors such as Horace Walpole (1717-1797; Hieroglyphs; The castle of Otranto), Jacques Cazotte (1719-1792; Suite des Mille et une nuits; Le diable amoureux), and William Beckford (1760-1844; Vathek; Épisodes). Although it has often been suggested that the 'fabulous' current in European literature instigated by the Thousand and one nights and refashioned by the Oriental tale was obscured by the new realism of the bourgeois novel, it is more likely that this tendency survived within these esoteric and Gothic strands, to re-emerge more forcefully in Romanticism in the nineteenth century. It appears to be more correct to say that, at least from the eighteenth century onwards, fantastic and realist types of literature evolved side by side and influenced each other. Within this process, the initial exoticism of the Thousand and one nights became less visible and was transformed into other devices of psychological or supernatural estrangement. ${ }^{20}$

An example of the tendencies summarized above is the intriguing novel Manuscrit trouvé à Saragosse by the Polish-French writer, traveller, and diplo-

20 Richard van Leeuwen, 'Religion and Oriental Tales in the 18th Century: The Emergence of the Fantastic Genre,' in: Aboubakr Chraïbi and Ilaria Vitali, eds, Variations françaises sur les Mille et une nuits: quelles versions pour quelles effets? Francofonia; studi e ricerche sulle letterature di lingua francese 69 (Autumn, 2015) $35^{-5}$. 
mat Jean Potocki (1761-1815). This novel is not only the account of a princely initiation, but also combines the influences of orientalism (Thousand and one nights) and the exploration of esoteric knowledge. In the end the story attempts to situate these elements within an 'enlightened' view of the world. Within the new epistemological approaches to the Orient and its historical and intellectual contexts that emerged in the eighteenth century, Jean Potocki stands out not merely as a remarkable figure, but rather as the embodiment of the spirit of his age. His inquisitive mind, his interest in the sciences, rational thought, and belles-lettres, his inclination towards adventures and travelling, and his interference in political and diplomatic events could not but lead to a vivid interest in the Orient, and, more specifically, in Oriental storytelling and the Thousand and one nights. Potocki's fascination with the Orient was directed at scholarly, literary, and practical aims. He advocated the foundation of a Russian Academy of Oriental Languages, after the Austrian example, and attempted to design policies for the stimulation of Asian trade. His interest is more directly expressed, however, through his own experiences in the Orient during his journeys to Spain and Morocco, Turkey and Egypt, and Mongolia and the Caucasus. These experiences are recorded in his travel accounts, which are of both scholarly and biographical interest. Potocki enjoyed immersing himself in the Oriental environment, and in his Voyage en Turquie et l'Égypte he relates how he roams through the alleys of Istanbul, immersing himself in their peaceful and tranquil atmosphere, and how he dons Oriental dress when he sets out for Egypt, as was the custom of truly adventurous travellers of the period. ${ }^{21}$ With keen interest he describes the customs of the Turks, Egyptians, and Moroccans, focusing particularly on their morale, their psychological attitudes and behaviour, which differentiates them from Europeans.

At an early stage, Potocki showed an interest in Oriental storytelling, and in his aforementioned Voyage en Turquie et en Égypte, published in 1784, when he was twenty-three, Potocki interspersed his letters with stories and anecdotes, some quoted from, for instance, a storyteller in a coffeehouse in Constantinople, others written by himself, inspired by his readings of Oriental tales. This interest is obvious, too, throughout the account of his journey to Morocco in 1791, in which he refers to the Thousand and one nights on various occasions. When visiting a tribal chief Potocki wraps his present in four silk handkerchiefs, as the mother of Aladdin did in the famous story in Galland's Mille et une nuits. ${ }^{22} \mathrm{He}$ remarks that the sultan refers to himself as 'emir al-moumenin',

21 Jean Potocki, Voyage en Turquie et en Égypte, Serge Plantureux, ed. (Paris, 1999).

22 Ibid., 27. 
a term translated by Galland as 'Commandeur des Croyants', one of the titles of the caliph. ${ }^{23}$ At other places he explicitly refers to the Thousand and one nights in his descriptions of specific Moroccan phenomena, such as the town crier. ${ }^{24}$ In Fez, Potocki asks a young student to procure a copy of the Thousand and one nights for him, which, according to the student, is known in Morocco as the 'Three hundred and fifty-four nights'. The student does not succeed in finding a copy, but he returns with a work of a similar genre, called, according to Potocki, Giafar et Barmaki, in which part of the Thousand and one nights' stories can be found. Potocki reads the beginning of the text in which it is related how a sultan, chasing a white gazelle, enters an enchanted castle, covered with valuable tiles. $^{25}$

It is clear from the passages in his travel accounts that Galland's Mille et une nuits was an important source of knowledge for Potocki and a frame of reference for his observations of Moroccan life and society, heeding Galland's remark that the work contained all the information about the manners and customs of the Orientals that an interested reader might need. It seems plausible to assume that the combination of his readings of the Mille et une nuits and his impressions of Morocco together provided the inspiration for his great literary project Manuscrit trouvé à Saragosse. This suggestion is strengthened by Potocki's statement that during his stay in Madrid he befriended the Moroccan ambassador to Spain, Sidi Mohammed Bin-Otman, who told him many Oriental stories, which he intended to write down sometime. ${ }^{26}$ One of the stories of Bin-Otman is inserted into the account itself. ${ }^{27}$ Apparently, during his journey through Spain and Morocco Potocki collected material, ideas, and impressions from various sources, which, together with Galland's Mille et une nuits, gradually became the first drafts of the Manuscrit. Just as in the case of the Thousand and one nights, oral sources were important, reflecting the authentic act of storytelling, which is also prominent in the work itself. They were combined with other sources, which, like the Nights, were put together in a collection over a long stretch of time, being reordered and recomposed various times. Thus, the textual history of the Manuscrit to a large extent resembles the complex process in which the Thousand and one nights, at least its European branch, took shape.

\begin{tabular}{ll}
\hline 23 & Ibid., 24. \\
24 & Ibid., 57. \\
25 & Ibid., 6o-61. \\
26 & Ibid., 23-24. \\
27 & Ibid., 53.
\end{tabular}


These parallels between Manuscrit trouvé à Saragosse and the Thousand and one nights, with regard to the nature of the sources and the process in which the material was gathered in a single work, are not without significance. They strengthen the generic connections between the two works, since they resulted in both cases in a broad diversity of material that was finally incorporated in the collections, ranging from histoires galantes to scientific compendiums, from fairy tales to edifying allegories, from chivalrous tales to love stories. Moreover, in both cases they explain the formal structure of the work as a seemingly endless labyrinth of stories, which are loosely connected to each other, or embedded in each other, and do not seem to lead to a clear denouement. Although the suspense is upheld by the connection between the framing story and the embedded stories, only at the end is a plot revealed that gives coherence to the collection as a whole and explains its many digressions, reconciling, so to speak, the 'sense of an ending' with the narrative device of postponement.

The origin and growth of the two texts thus show that their concepts are similar, a similarity that is further elaborated in the structure of Manuscrit trouvé à Saragosse. Like the Thousand and one nights, the Manuscrit has a layered structure, which consists of a framing story and a chain of embedded stories. It is built on the by now familiar dialogic structure of characters in a framing story telling tales to each other that are embedded in the frame. The conceptual and formal resemblances, with their elements of self-reflexivity and meta-fictionality, link the Manuscrit first of all with the framing story of the Thousand and one nights, the story of 'Shahriyâr and his brother', in which the origin and the rationale of the storytelling are explained. ${ }^{28}$ In the Manuscrit we have the 'Avertissement', which relates the discovery of the Manuscrit by a French officer, the possession of which saves him when his company is captured by Spanish troops. The text is subsequently dictated to the officer by the Spanish captain, while he resides in the Spaniard's house. The narrative does not return to this level, but in the final paragraphs of the book the hero, Alphonse van Worden, explains how he hides a copy of the book in an iron chest, to be found by his descendants. This is a significant procedure, since it was the way of the converted Muslims (Moriscos) after the Reconquista to hide their religious texts, and it is therefore suggested that the Manuscrit contains a life-story that is not part of official, well-known, history, but rather of a secret history, a hidden part of Spain's past.

28 For a summary of the framing story, see: Marzolph and Van Leeuwen, The Arabian Nights Encyclopedia. 
On the second level we meet the protagonist Alphonse van Worden, who is travelling through the Sierra Morena and who spends the night in the inn Venta Quemada, an old Moorish stronghold where he meets the sisters Emina and Zibbedee for the first time. The sisters not only try to seduce Alphonse, but also tell him the story of the Cassar-Gomelez and the history of the Gomelez family, which is interrupted by daybreak. This scene, of course, calls to mind the image of Shahriyar and the two sisters Shahrazad and Dunyazad in the framing story of the Thousand and one nights, with its entwinement of eroticism and storytelling. In both cases it is the women who aspire to marry the heroes, Shahriyar and Alphonse. The parallel between Shahriyar and Alphonse is further strengthened by their conforming to ideal types of masculinity. They are both powerful heroes, full of masculine virtues, and paragons of noble integrity. Both, however, have in some sense become isolated in their masculinity and in the symbolic narrowness of their status and personality, and are now re-connected with various aspects of femininity, Shahriyar through the combination of eroticism and storytelling, Alphonse through eroticism and the disclosure of a hidden part of his family's history, because he discovers that he is a descendant of the Moorish Gomelez family through his mother.

In the case of Shahriyar a long trajectory of 'seduction' ensues, which is meant to avert certain death. In the case of Alphonse, the seduction is meant to have him abandon his faith and convert to Islam. This is countered, however, by the stories of the hermit and the threat of the Inquisition, subjecting Alphonse to dangers from both sides. In both cases, a kind of deadlock is created, a situation of liminality in which the position of the protagonists is, so to speak, renegotiated. Through the prolongation of the dilemma, through the postponement of the final decision, visions of life and the world are evoked in stories and discourses, with the intention to reconstruct the vision of the protagonist and enable a denouement: The rigid, monolithic, worldviews of Shahriyar and Alphonse have to be changed in order to break the deadlock, and this can be achieved only by the interference of the imagination and human ingenuity, by subjecting Shahriyar and Alphonse to the power of the human intellect and constructing a vision of the world in which the death-threat is eliminated.

In the framing story of the Thousand and one nights the deadlock caused by Shahrazad's postponement of her execution is part of a much more farreaching stagnation, which is the inability of Shahriyar to beget successors. In the story it is not explained why the first marriage of Shahriyar, with the adulterous spouse, remained childless, but by installing a regime in which he marries a virgin every night who is subsequently executed in the morning, all means of procreation are aborted. The king will have no sons to succeed him, and the dynasty will come to an end. The continuation of time will definitively 
be interrupted. Likewise, in Manuscrit trouvé à Saragosse, it is the dynasty of the Gomelez that seems to have reached its end. After a glorious past, the dynasty is looking for a new sheykh to secure its survival, and Alphonse is chosen as a husband for Emina and Zibbedee to safeguard the continuation of the family.

In both narratives the state of stagnation, the interruption of the passage of time, is related to the solid, unambiguous male identity of the protagonists, which is buttressed with forms of authority and the threat of physical violence, personified by Shahriyar and the Inquisition. This form of monolithic identity and authority is linked to masculine qualities and juxtaposed with a nonviolent strategy of seduction, persuasion, and imagination, associated with feminine ingenuity. Evidently, the use of force would not be an option for Shahrazad or Emine and Zibbedee, since not only do they lack the required physical means, but the death of Shahriyar and Alphonse would not solve the underlying problem. The only solution lies in persuasion and the procuring of affection, a transformation of the rigid mentality of the males. Thus, in both cases it is feminine imagination that penetrates into the stronghold of masculinity to achieve a gradual softening of the rigid identification with power and violence. In both cases, the story ends with the revealing of the newborn children, which are only half-consciously begotten by Shahriyar and Alphonse, but which ensure the continuation of the dynasty and restore the regular passage of time.

It is, of course, no coincidence that storytelling takes such a prominent place in the undermining of the violent form of power. In both narratives it is suggested that the threat of violence is related to a narrow and monolithic worldview, which has no vision of the complexity of reality and the possible inclusion of what is seen as different and alien. In the case of Shahriyar it is the feminine element that is repressed; in the case of Alphonse it is the Moorish part of his identity that is not acknowledged. In both cases the narrow, inflexible worldview is relativized by impregnating it with the imagination and alternative visions contained in stories, life accounts etc. In the end, the incorporation of the alien element and the adoption of a form of plurality acknowledging the multi-faceted nature of reality produce a new dynamism, new life, and a new future. By showing how the imagination can intervene in the course of events, a new synthesis is achieved between male and female, Spanish and Moorish elements of identity based on the acceptance of the complexity of reality.

The parallels summarized above show how profoundly the stories of Shahriyar and Shahrazad and the Manuscrit trouvé à Sarragosse are connected, but the influence of the Thousand and one nights is not limited to the framing story only. Parallels can also be traced with a type of story very common in Arabic 
literature in general and in the Thousand and one nights more particularly: the love romance. In these stories, which resemble European medieval romances, a young hero, usually a prince or a merchant's son, sets out to find his beloved and, before reaching the object of his desire, roams through a world of wonders, enticements, and threats, in which he has to find his way. Often he has to cross magical landscapes, enter enchanted spaces, and combat mysterious enemies. After he has reached his goal, he returns home and is re-incorporated into his community, usually as a successor to the throne, now comfortably married. This pattern is evident in the Manuscrit trouvé à Sarragosse as well, where Alphonse, a brave young officer, with a bright future, sets out on a journey and is suddenly caught in a rough landscape full of mysterious forces, strange events, and physical dangers. He has entered a labyrinth that shakes all his certainties and convictions, and from which he has to find a way out before he can continue on his journey and assume his position at the court of the king.

Romances of this kind are usually interpreted as stories of initiation, in which an adolescent hero is subjected to a rite of passage before he can fulfil his predestined role in society. The hero is thrown into a state of uncertainty and liminality, in which his identity has been called into question, and in which his courage, intelligence, and ingenuity are tested. He has to confront dangers, allurements, dilemmas, and obstacles, and show that he can overcome them and take the correct decisions. In the meantime his personality is reshaped to be fit to fulfil his required tasks in the service of the dynasty and the community. Alphonse's predicaments seem to serve the same purpose of initiation. The state of liminality and uncertainty is symbolized by the harsh landscape of the Sierra Morena, full of brigands and unexplainable forces. His steadfastness and determination are tested in several ways; he is confronted with enemies, frightening mirages, horrors, dreams, and temptations, which all unhinge his former identity and radically revise his vision of himself. Only after he has passed his several trials successfully, that is, after he has secured the continuation of the Gomelez dynasty without relinquishing his Catholic faith, can he proceed to his destination and become what he is destined to be. As in the Arabic romances, Alphonse's initiation into sexuality and eroticism is an important element of his formation as an adult man. Significantly, the journey of initiation completed by Alphonse is mirrored by the story of the Gomelez sheykh about his own journey when he was an adolescent and destined to assume the leadership of the family.

The idea of initiation is also the main conceptual component of cycles of the mirror-for-princes type, such as the Sevenviziers, which consist of a framing tale in which the elements of the intrigue are explicated and a number of inserted stories. As in Manuscrit trouvé à Saragosse, in most narratives of this type the 
conduct of a young prince, often his addiction to women, threatens the survival of the dynasty and the empire, and the prince is saved by a learned vizier. In Manuscrit it is the figure of the sheykh of the Gomelez, who turns out to have been arranging and supervising the 'education' of Alphonse, and thereby takes the place of Shahrazâd, but the elements of seduction and trial and the juxtaposition of stories, discourses, etc., link the work to the genre of the mirrorfor-princes, which in the end results in the intellectual and moral education of the prince, but also, ultimately, of the reader.

It has been argued that it is erroneous to consider the Manuscrit as belonging to the tradition of the fantastic novel, which at the end of the eighteenth century was represented, for instance, by Cazotte's Le diable amoureux and Beckford's Vathek. It should rather be seen as an anti-fantastic novel, since all occurrences of supernatural forces and events are in the end disclosed to have been illusions and manipulations of the sheykh of the Gomelez. Every suggestion of the existence of magical forces is wiped away, as all strange events can be rationally explained. Still, even if Manuscrit trouvé à Saragosse is not a fantastic novel, it is a novel in which the relationship between reality and potentially supernatural forces is explored, both as part of a complex reality and as an aspect of human perception and the human psyche. Even if, for Potocki's rational mind, there is no supernatural realm, reality is still more complex than it seems. It is this explanation of the nature of reality that links Manuscrit trouvé à Saragosse with other novels that can be more unequivocally called 'fantastic' and in which the author attempts to lay bare deeper layers of reality, both inside the human mind and in the material world.

Our analysis above shows that it is justified to conclude that Manuscrit trouvé à Saragosse is a pivotal work in the transmission of Oriental, Arabic influences to European literature, both because of its ambitious concept and through its use of Arabic literary sources. Interestingly, the incorporation of Arabic elements is not restricted to the formal structure of the work, but is also part of its theme, which deals chiefly with Islam as a repressed part of the identity of Spain. On both these levels, the model after which the work was moulded is the Thousand and one nights, which provided formal as well as conceptual matrices. Apart from the clear formal parallels, perhaps the main element taken from the Thousand and one nights is the use of the evocation of narrative, imaginary, and illusionary worlds as a strategy to undermine rigid, ideological visions of reality. The sheykh of the Gomelez conjures up an illusionary world filled with magical, enacted, happenings and performance as a means to disrupt Alphionse's one-dimensional worldview, which is based on his being brought up with the solid values of Christian Spain. The suggestion of magic is particularly conducive to this deconstruction, since it is contradictory 
to both Christian and rationalistic views of reality. Moreover, in the European mind, magic was specifically associated with the Orient, and it thus contributes to the sense of estrangement that Alphonse experiences in the Sierra Morena. In the end, the magical events turn out to be illusions concocted by the sheykh, but the narrative shows that the evocation of 'unreality' can help to reconstruct visions of reality and thereby influence the course of events, as often occurs in the Thousand and one nights.

Potocki's aim with this deconstruction seems to be the re-acknowledgement of the Moorish component of the Spanish past, which has remained hidden and slumbering without being recognized. The Gomelez have, so to speak, been isolated from the mainstream of history and condemned literally to an underground existence. It is conspicuous that they are described as Shiites, which implies that also in the Muslim periods of Spanish history they were a minority community, not incorporated into the main institutions of authority and always planning to penetrate into the centres of power. Moreover, the Shiites are allowed to conceal their true religious identity through dissimulation, or taqiyya, and have an important messianic component in their doctrines. These aspects evidently enhanced Potocki's ability to create suspense and to play with the idea of a hidden community scheming to conquer the world. And the fact that they are hidden is part of their subversive strategies.

In the end all these disquieting elements are relegated to their proper places. The magic turns out to be simple manipulations, and the rationalist view of reality is restored. The stronghold of the Gomelez in the Sierra Morena is dismantled, and their dynasty continues to prosper, not in Spain, but in North Africa. This is achieved, however, only after Alphonse has acknowledged his relationship to the Gomelez family and has accepted it as part of his identity. Only in this way can the Gomelez family emerge out of their isolation and be taken up in the course of history, as Muslim rulers in North Africa. Only by acknowledging its Islamic component can Spanish history be complete, although it is not necessary to give up the Christian component: In the end each element has its proper place. All these developments are the result of the esoteric 'knowledge' of the sheykh of the Gomelez being re-injected into the realm of the visible world through the person of the prince, who is thus initiated into the secret of his descent and his true identity.

\section{Concluding Remarks}

All our examples in this chapter have in common that they revolve around the theme of initiation into some kind of esoteric knowledge, that of the prince/ 
vizier himself as a protagonist in his own adventures, or as a prince listening to the adventures of others. The narratives are layered and meant to instruct the reader, mainly through the instruction of the stories' heroes or through the exposure of fraudulent knowledge. The ultimate aim is to realize a middle course between belief and superstition, between the acknowledgement and exorcism of supernatural forces, between moral extremes and between human and divine interests. The prince/vizier is always in the centre of the process; he is the prism revealing the components of power and authority. He is the one who 'sacrifices' himself to bring hidden forces to the surface and anchor stability in the cosmic constellation. He, one might say, collects subconscious fears and fantasies, slays them like fierce monsters, and resigns them to their confined domain within the cosmic structure. And, usually, the prince/vizier is predestined to fulfil this task.

All our examples examined above, finally, have in common that they are composite narratives, incorporating components from various genres, historical and fictional, from various media, oral and written, from various times, ancient and premodern, and from various traditions, religious and political. And, moreover, they combine elements from various cultural traditions, Oriental and Western, Taoist and Buddhist, Islamic and Hindi, Jewish, Greek, and Persian. In spite of the many resemblances in form and content, it is difficult to speculate about relationships and connections. Nevertheless, we can perceive a pattern showing a strong connection between thematic and formal elements within the various literary traditions, which perhaps have not intermingled without obstacles, but which still seem to have 'discovered' similar strategies to convey ideological views and similar forms to ensure the efficacy of the medium of text. The aim of the texts discussed in this and the previous chapter is, invariably, to situate kingship within the broader frameworks of religion and the supernatural, to convey a worldview in which the authority of the king is naturalized and harmonized with cosmic forces. 